\title{
INTRODUCTION
}

\section{Lionfish: a major marine invasion}

\author{
Mark A. Hixon ${ }^{1, *}$, Stephanie J. Green ${ }^{2}$, Mark A. Albins ${ }^{3}$, John L. Akins ${ }^{4}$, \\ James A. Morris Jr. ${ }^{5}$ \\ ${ }^{1}$ Department of Biology, University of Hawai'i at Mānoa, Honolulu, HI 96822, USA \\ ${ }^{2}$ Center for Ocean Solutions, Stanford University, Monterey, CA 93940, USA \\ ${ }^{3}$ Dauphin Island Sea Lab, University of South Alabama, Dauphin Island, AL 36528, USA \\ ${ }^{4}$ Reef Environmental Education Foundation, Key Largo, FL 33037, USA \\ ${ }^{5}$ Center for Coastal Fisheries and Habitat Research, National Centers for Coastal Ocean Science, National Ocean Service, \\ National Oceanic and Atmospheric Administration, Beaufort, NC 28516, USA
}

\begin{abstract}
Indo-Pacific lionfish Pterois volitans/miles were likely introduced to Florida coastal waters via the aquarium trade and have spread rapidly along the southeastern coast of the United States and throughout the greater Caribbean region, including Bermuda and the Gulf of Mexico. This mesopredator has strong consumptive effects on native demersal fishes, especially on coral reefs but also including a variety of other nearshore habitats. The invader may also have substantial indirect effects on reef ecosystems by overconsuming ecologically important species. Given growing concern over what is likely the most damaging marine fish invasion to date globally, this Theme Section presents findings reported during a lionfish symposium at the Gulf and Caribbean Fisheries Institute annual conference convened in Panama City, Panama, in November 2015. New findings include mechanisms that enhance the success of the invader, the extremely broad and variable diet of invasive lionfish, the ecological effects of the invader on native fish populations in various environmental contexts, and non-consumptive interactions between invasive lionfish and native predators.
\end{abstract}

KEY WORDS: Lionfish · Invasion · Predation $\cdot$ Reef fishes

The invasion of tropical and subtropical Western Atlantic coastal ecosystems by Indo-Pacific lionfish Pterois volitans/miles (Fig. 1) first became apparent in the early 2000s when multiple individuals were documented off the coast of North Carolina (Whitfield et al. 2002). Lionfish were likely introduced through aquarium releases (Semmens et al. 2004), and not by Hurricane Andrew (www.sciencemag.org/ news/2010/04/mystery-lionfish-dont-blame-hurricaneandrew). Their geographic spread has been rapid and broad: up the eastern seaboard of the United States as far north as Rhode Island (summer recruits dying back to Cape Hatteras during the winter), across to Bermuda, throughout the Bahamas and the greater Caribbean region to Brazil, and into the Gulf of Mexico (Schofield 2010). Invaded habitats

\footnotetext{
*Corresponding author: hixonm@hawaii.edu
}

include coral reefs, other hard seafloors, seagrass beds, mangroves, river estuaries, and various artificial structures, and individuals have been sighted from manned submersibles as deep as $300 \mathrm{~m}$ (reviews by Morris 2012, Albins \& Hixon 2013, Côté et al. 2013a). This unprecedented invasion has been facilitated by rapid growth rates of individual lionfish (Pusack et al. 2016), exponentially increasing local population sizes (Green et al. 2012, Albins \& Hixon 2013), and resulting high densities (Green \& Côté 2009, Kulbicki et al. 2012, Dahl \& Patterson 2014), indicating that these largely piscivorous invaders are quickly converting native prey into lionfish biomass.

The success of lionfish has likely been enhanced by the lack of substantial biotic resistance by invaded communities. Native predators are apparently de-

() Authors M.A.H., S.J.G., M.A.A., J.L.A., and the USA Government 2016. Open Access under Creative Commons by Attribution Licence. Use, distribution and reproduction are unrestricted. Authors and original publication must be credited.

Publisher: Inter-Research · www.int-res.com 


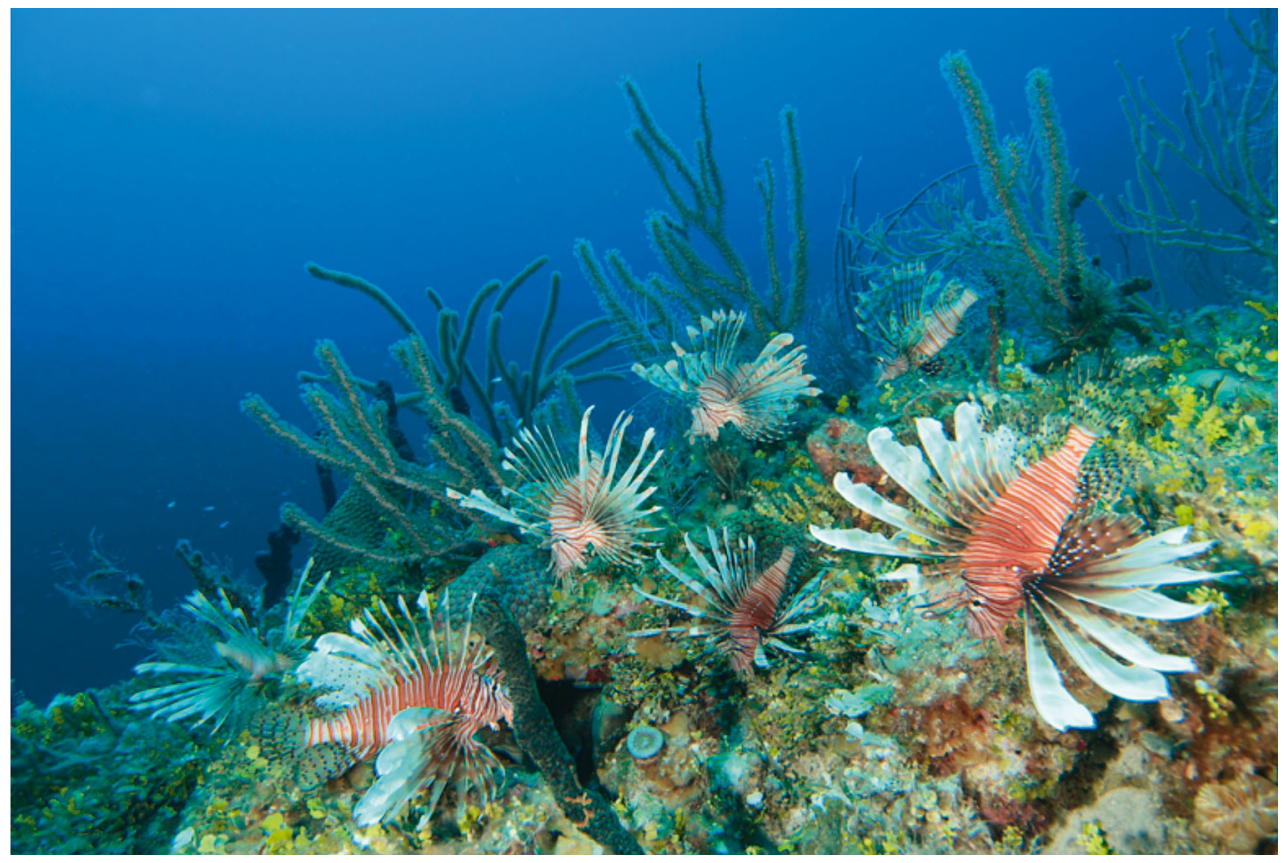

Fig. 1. Invasive red lionfish Pterois volitans in the Bahamas (photo by Rich Carey)

terred by the unusual shape, cryptic coloration, and venomous spines of lionfish, although there is debate regarding whether large native groupers are a major threat to the invader (Mumby et al. 2011, Hackerott et al. 2013, Valdivia et al. 2014, Bruno et al. doi: 10.7287/peerj.preprints.139v1, Mumby et al. doi: 10.7287/peerj.preprints.45v1). Few parasites attack invasive lionfish (Sikkel et al. 2014), native mesopredators appear to be ineffective competitors (Albins 2013), and even highly territorial damselfish do not chase them (Kindinger 2015). Additionally, lionfish use a variety of feeding behaviors, including ambushing and corralling prey (Morris \& Akins 2009), as well as blowing jets of water at prey (Albins \& Lyons 2012). Combined with cryptic coloration and unusual appearance, such flexible feeding behavior apparently allows high consumption rates of native prey (Albins \& Hixon 2008, Côté \& Maljković 2010, Green et al. 2011, Cure et al. 2012). To date, the only local controls of the invasion have been targeted fisheries and removals by divers, especially lionfish derbies (Barbour et al. 2011, Frazer et al. 2012, Morris 2012). In the absence of such local controls, lionfish eventually reach densities where they may become self-limiting (Benkwitt 2013).

Lionfish are rapidly depleting local abundances of native reef fishes, as shown by both controlled field experiments (Albins \& Hixon 2008, Albins 2013, 2015, Green et al. 2014, Benkwitt 2015) and observational studies (Green et al. 2012, Benkwitt 2016a).
Lionfish diets comprise a broad variety of native fishes and invertebrates (Morris \& Akins 2009, Muñoz et al. 2011, Valdez-Moreno et al. 2012, Côté et al. 2013b, Dahl \& Patterson 2014), including not only small species but also the juveniles of larger species. Native prey consumed as juveniles include commercially and recreationally important groupers and snappers, as well as ecologically important grazers such as surgeonfishes and parrotfishes, which keep reef surfaces clean so that corals can flourish (review by Hixon 2015). Invasive lionfish also have non-consumptive effects, in that their mere presence inhibits grazing activity by these reef fishes (Kindinger \& Albins 2016). The list of native species consumed by lionfish will undoubtedly continue to grow with additional diet studies from across the invaded region. However, studies of lionfish prey selection suggest that solitary, narrow-bodied fish that reside near the seafloor are most vulnerable (Green \& Côté 2014). Importantly, extirpation of native fishes is evident (Albins 2015). Consequently, the lionfish invasion has been identified as one of the greatest emerging threats to global biodiversity (Sutherland et al. 2010).

Given this unprecedented invasion, a symposium on invasive lionfish (the 8th thus far) was hosted by the 68th Gulf and Caribbean Fisheries Institute annual conference in Panama City, Panama, on November 11, 2015, funded by the Florida Sea Grant Program, the Florida Fish and Wildlife Conservation 
Commission, the National Oceanic and Atmospheric Administration, and the Reef Environmental Education Foundation. With over 80 submissions from across the invaded region, the symposium featured 24 talks and as many posters, presenting a broad range of information related to lionfish biology, the ecological and economic effects of the invasion, and efforts to manage the invasion. The 9 articles in this Theme Section reflect much of the diversity of topics covered during the symposium:

Several papers focus on the success of lionfish as invasive species. Stevens et al. (2016, this Theme Section [TS]) found that the skin bacteria of lionfish show antibacterial activity against known fish pathogens, indicating that resistance to disease may be added to the list of mechanisms that enhance the success of the invader. One established measure of success is that invasive lionfish are generalist mesopredators. Harms-Tuohy et al. (2016, this TS) used DNA metabarcoding to characterize the complete gut contents of lionfish in Puerto Rico, finding that the diets are even broader than detectable by traditional visual identification: 63 lionfish had consumed 39 native fish species representing 16 families. Eddy et al. (2016, this TS) further documented the broad diet of the invader. Lionfish in Bermuda, near the northern limit of the invasive range, consume more crustaceans and fewer fishes than further south.

Most papers examine the ecological effects of the invasion. Dahl et al. (2016, this TS) compared fish communities on artificial reefs in the northern Gulf of Mexico before and after the invasion, and conducted a field experiment comparing no versus single versus repeated removals of lionfish. Lionfish rapidly recolonized removal reefs. Although the experiment was confounded by possible effects of the Deepwater Horizon oil spill, there was a clear indication that smaller resident fishes were less abundant following the invasion. Working in Panama, Palmer et al. (2016, this TS) conducted a shorter-term lionfish removal experiment that also indicated a negative effect on the abundance of several native fishes, yet no effect on the genetic diversity of the bicolor damselfish Stegastes partitus.

A field experiment by Ingeman (2016, this TS) in the Bahamas demonstrated that invasive lionfish add substantial density-independent mortality of the native fairy basslet Gramma loreto to the density dependence caused by native predators, pushing some local populations toward extirpation. Aquarium experiments by Kindinger \& Anderson (2016, this TS) showed that lionfish prefer fairy basslet over blackcap basslet G. melacara, whereas a native meso- predator, graysby grouper Cephalopholis cruentata, prefers blackcaps. Thus, interactions among native prey, native predators, and invasive lionfish may have unforeseen indirect effects on community interactions. Benkwitt (2016b, this TS) documented movements and behaviors of lionfish on patch reefs in the Bahamas, showing that at higher densities, lionfish forage over surrounding seagrass meadows at night. These findings indicate that localized culling of lionfish may limit the area over which the invaders affect native fish populations.

The ecological effects of lionfish may be moderated by large native fishes having negative effects on the invader. Red grouper Epinephelus morio defend karst solution holes in Florida Bay. Ellis \& Faletti (2016, this TS) experimentally demonstrated that, relative to holes where both predators were excluded, juvenile reef fish abundance was much higher where only grouper were present, much lower where only lionfish were present, and not different if both predators were present. This result indicates that grouper somehow inhibit piscivory by lionfish, which switch to invertebrate prey in the presence of the larger native predator.

In summary, the lionfish invasion is unprecedented and potentially catastrophic from multiple perspectives. Given that eradication is currently not possible with the tools and resources available, the possibility remains that this major marine fish invasion will permanently alter the ecology of coastal ecosystems of the greater Caribbean region and southeastern United States, especially coral-reef systems already degraded by various human activities (Albins \& Hixon 2013).

Acknowledgements. As organizers of the lionfish symposium, we are especially grateful for the enthusiastic support and generous funding arranged by the leaders of the Gulf and Caribbean Fisheries Institute: Robert Glazer, Leroy Creswell, and Alejandro Acosta. Special thanks to MEPS editors Charles Birkeland, Tim McClanahan, Ivan Nagelkerken, and Christine Paetzold for working with guest editors Mark Albins, Stephanie Green, and Mark Hixon to produce this Theme Section. Ultimately, we thank the many colleagues who participated in the lionfish symposium, expert peer reviewers, and all those seeking to understand and control the lionfish invasion. M.A.H. acknowledges funding from the National Science Foundation (grants 0851162 and 1233027), and funding to S.J.G. was provided by a David H. Smith Conservation Research Fellowship. We thank the Florida Sea Grant Program, the Florida Fish and Wildlife Conservation Commission, the Reef Environmental Education Foundation, the NOAA National Ocean Service, Office of the National Marine Sanctuaries, the National Centers for Coastal Ocean Science, and the NOAA National Marine Fisheries Service, Office of International Affairs, for supporting the lionfish symposium. 


\section{LITERATURE CITED}

Albins MA (2013) Effects of invasive Pacific red lionfish (Pterois volitans) versus a native predator on Bahamian coral-reef fish communities. Biol Invasions 15:29-43

Albins MA (2015) Invasive Pacific lionfish Pterois volitans reduce abundance and species richness of native Bahamian coral-reef fishes. Mar Ecol Prog Ser 522: 231-243

> Albins MA, Hixon MA (2008) Invasive Indo-Pacific lionfish Pterois volitans reduce recruitment of Atlantic coral-reef fishes. Mar Ecol Prog Ser 367:233-238

Albins MA, Hixon MA (2013) Worst case scenario: potential long-term effects of invasive predatory lionfish (Pterois volitans) on Atlantic and Caribbean coral-reef communities. Environ Biol Fishes 96:1151-1157

Albins MA, Lyons PJ (2012) Invasive red lionfish Pterois volitans blow directed jets of water at prey fish. Mar Ecol Prog Ser 448:1-5

> Barbour AB, Allen MS, Frazer TK, Sherman KD (2011) Evaluating the potential efficacy of invasive lionfish (Pterois volitans) removals. PLOS ONE 6:e19666

> Benkwitt CE (2013) Density-dependent growth in invasive lionfish (Pterois volitans). PLOS ONE 8:e66995

> Benkwitt CE (2015) Non-linear effects of invasive lionfish density on native coral-reef fish communities. Biol Invasions 17:1383-1395

> Benkwitt CE (2016a) Central-place foraging and ecological effects of an invasive predator across multiple habitats. Ecology 97:2729-2739

Benkwitt CE (2016b) Invasive lionfish increase activity and foraging movements at greater local densities. Mar Ecol Prog Ser 558:255-266

Côté IM, Maljković A (2010) Predation rates of Indo-Pacific lionfish on Bahamian coral reefs. Mar Ecol Prog Ser 404: 219-225

Côté IM, Green SJ, Hixon MA (2013a) Predatory fish invaders: insights from Indo-Pacific lionfish in the western Atlantic and Caribbean. Biol Conserv 164:50-61

Côté IM, Green SJ, Morris JA, Akins JL, Steinke D (2013b) Diet richness of invasive Indo-Pacific lionfish revealed by DNA barcoding. Mar Ecol Prog Ser 472:249-256

> Cure K, Benkwitt CE, Kindinger TL, Pickering EA, Pusack TJ, McIlwain JL, Hixon MA (2012) Comparative behavior of red lionfish Pterois volitans on native Pacific versus invaded Atlantic coral reefs. Mar Ecol Prog Ser 467: 181-192

> Dahl KA, Patterson WF (2014) Habitat-specific density and diet of rapidly expanding invasive red lionfish, Pterois volitans, populations in the northern Gulf of Mexico. PLOS ONE 9:e105852

- Dahl KA, Patterson WF, Snyder RA (2016) Experimental assessment of lionfish removals to mitigate reef fish community shifts on northern Gulf of Mexico artificial reefs. Mar Ecol Prog Ser 558:207-221

> Eddy C, Pitt J, Morris JA Jr, Smith S, Goodbody-Gringley G, Bernal D (2016) Diet of invasive lionfish (Pterois volitans and $P$. miles) in Bermuda. Mar Ecol Prog Ser 558: 193-206

Ellis RD, Faletti ME (2016) Native grouper indirectly ameliorates the negative effects of invasive lionfish. Mar Ecol Prog Ser 558:267-279

Frazer TK, Jacoby CA, Edwards MA, Barry SC, Manfrino CM (2012) Coping with the lionfish invasion: can targeted removals yield beneficial effects? Rev Fish Sci
20:185-191

> Green SJ, Côté IM (2009) Record densities of Indo-Pacific lionfish on Bahamian coral reefs. Coral Reefs 28:107

Green SJ, Côté IM (2014) Trait-based diet selection: prey behaviour and morphology predict vulnerability to predation in reef fish communities. J Anim Ecol 83: 1451-1460

> Green SJ, Akins JL, Côté IM (2011) Foraging behaviour and prey consumption in the Indo-Pacific lionfish on Bahamian coral reefs. Mar Ecol Prog Ser 433:159-167

Green SJ, Akins JL, Maljković A, Côté IM (2012) Invasive lionfish drive Atlantic coral reef fish declines. PLOS ONE 7:e32596

Green SJ, Dulvy NK, Brooks AM, Akins JL, Cooper AB, Miller S, Côté IM (2014) Linking removal targets to the ecological effects of invaders: a predictive model and field test. Ecol Appl 24:1311-1322

Hackerott S, Valdivia A, Green SJ, Côté IM and others (2013) Native predators do not influence invasion success of Pacific lionfish on Caribbean reefs. PLOS ONE 8:e68259

> Harms-Tuohy CA, Schizas NV, Appeldoorn RS (2016) Use of DNA metabarcoding for stomach content analysis in the invasive lionfish Pterois volitans in Puerto Rico. Mar Ecol Prog Ser 558:181-191

Hixon MA (2015) Reef fishes, seaweeds, and corals: a complex triangle. In: Birkeland C (ed) Coral reefs in the Anthropocene. Springer, Dordrecht, p 195-215

Ingeman KE (2016) Lionfish cause increased mortality rates and drive local extirpation of native prey. Mar Ecol Prog Ser 558:235-245

Kindinger TL (2015) Behavioral response of native Atlantic territorial three spot damselfish (Stegastes planifrons) toward invasive Pacific red lionfish (Pterois volitans). Environ Biol Fishes 98:487-498

> Kindinger TL, Albins MA (2016) Consumptive and nonconsumptive effects of an invasive marine predator on native coral-reef herbivores. Biol Invasions (in press), doi: 10.1007/s10530-016-1268-1

Kindinger TL, Anderson ER (2016) Preferences of invasive lionfish and native grouper between congeneric prey fishes. Mar Ecol Prog Ser 558:247-253

Kulbicki M, Beets J, Chabanet P, Cure K and others (2012) Distributions of Indo-Pacific lionfishes Pterois spp. in their native ranges: implications for the Atlantic invasion. Mar Ecol Prog Ser 446:189-205

Morris JA (ed) (2012) Invasive lionfish: a guide to control and management. Gulf and Caribbean Fisheries Institute Special Publication Series Number 1, Marathon, Florida

> Morris JA, Akins JL (2009) Feeding ecology of invasive lionfish (Pterois volitans) in the Bahamian archipelago. Environ Biol Fishes 86:389-398

> Mumby PJ, Harborne AR, Brumbaugh DR (2011) Grouper as a natural biocontrol of invasive lionfish. PLOS ONE 6:e21510

Muñoz RC, Currin CA, Whitfield PE (2011) Diet of invasive lionfish on hard bottom reefs of the Southeast USA: insights from stomach contents and stable isotopes. Mar Ecol Prog Ser 432:181-193

Palmer G, Hogan JD, Sterba-Boatwright BD, Overath RD (2016) Invasive lionfish Pterois volitans reduce the density but not the genetic diversity of a native reef fish. Mar Ecol Prog Ser 558:223-234

> Pusack TJ, Benkwitt CE, Cure K, Kindinger TL (2016) Invasive red lionfish (Pterois volitans) grow faster in the 
Atlantic Ocean than in their native Pacific Range. Environ Biol Fishes 99:571-579

Schofield PJ (2010) Update on geographic spread of invasive lionfishes (Pterois volitans [Linnaeus, 1758] and P. miles [Bennett, 1828]) in the Western North Atlantic Ocean, Caribbean Sea and Gulf of Mexico. Aquat Invasions 5:S117-S122

Semmens BX, Buhle ER, Salomon AK, Pattengill-Semmens CV (2004) A hotspot of non-native marine fishes: evidence for the aquarium trade as an invasion pathway. Mar Ecol Prog Ser 266:239-244

Sikkel PC, Tuttle LJ, Cure K, Coile AM, Hixon MA (2014) Low susceptibility of invasive red lionfish (Pterois voli$\operatorname{tans}$ ) to a generalist ectoparasite in both its introduced and native ranges. PLOS ONE 9:e95854

Stevens JL, Jackson RL, Olson JB (2016) Bacteria associated with lionfish (Pterois volitans/miles complex) exhibit antibacterial activity against known fish pathogens. Mar Ecol Prog Ser 558:167-180

Sutherland WJ, Clout M, Côté IM, Daszak P and others (2010) A horizon scan of global conservation issues for 2010. Trends Ecol Evol 25:1-7

Valdez-Moreno M, Quintal-Lizama C, Gómez-Lozano R, García-Rivas MdC (2012) Monitoring an alien invasion: DNA barcoding and the identification of lionfish and their prey on coral reefs of the Mexican Caribbean. PLOS ONE 7:e36636

Valdivia A, Bruno JF, Cox CE, Hackerott S, Green SJ (2014) Re-examining the relationship between invasive lionfish and native grouper in the Caribbean. PeerJ 2:e348

Whitfield PE, Gardner T, Vives SP, Gilligan MR, Courtenay WR, Ray GC, Hare JA (2002) Biological invasion of the Indo-Pacific lionfish Pterois volitans along the Atlantic coast of North America. Mar Ecol Prog Ser 235:289-297 